\title{
PERBEDAAN PSYCHOLOGICAL WELL-BEING ANTARA WANITA MENOPAUSE YANG BEKERJA DAN TIDAK BEKERJA
}

\author{
Debby Anggraini Daulay dan Nana Zahara Siregar \\ Universitas Sumatera Utara
}

\begin{abstract}
ABSTRAK
Masa menopause bagi beberapa wanita membuat wanita jadi lebih mudah tersinggung, sulit tidur, tertekan, gugup dan gelisah, kesepian, tidak sabar, tegang, cemas bahkan depresi. Bagi wanita yang tidak mampu menyesuaikan diri dengan kondisi ini akan mempengaruhi psychological well-beingnya. Psychological wellbeing adalah realisasi dan pencapaian penuh dari potensi psikologis seseorang. Psychological well-being dipengaruhi oleh peran yang dilakukannya dalam kehidupan sehari-hari. Saat ini banyak wanita yang tidak hanya berperan sebagai ibu rumah tangga tetapi juga menjadi wanita bekerja. Penelitian ini bertujuan untuk mengetahui perbedaan psychological well-being antara wanita menopause yang bekerja dan tidak bekerja. Hasil penelitian menggunakan independent sample t-test menunjukkan ada perbedaan psychological wellbeing antara wanita menopause yang bekerja dan tidak bekerja. Keenam dimensi dari psychological wellbeing juga menunjukkan adanya perbedaan antara wanita menopause yang berkerja dan tidak bekerja.
\end{abstract}

Kata-kata kunci: Psychological well-being, menopause, perempuan yang bekerja

\section{PSYCHOLOGICAL WELL-BEING DIFFERENCES AMONG EMPLOYED AND UNEMPLOYED MENOPAUSE WOMEN}

\begin{abstract}
Menopause may give rise to irritation, sleep trouble, depressed, nervousness, loneliness and anxiety for some women. These conditions would affect the psychological well-being of those who are unable to cope with problems associated with menopause. Psychological well-being is the realization and attainment of one's psychological potentials. Psychological well-being is affected by the roles of which one's chose in life. At the present time, many women do not only take the role of a housewife, but also as an employed worker. The present research is aimed to examine the psychological well-being among employed and unemployed menopause women. The results of this study showed significant psychological well-being differences between employed and unemployed menopause women.
\end{abstract}

Keywords: Psychological well-being, menopause, employed women

Menopause merupakan peristiwa alamiah yang pasti akan dialami setiap wanita dan tidak dapat dihindari. Namun bagi sebagian wanita, menopause dianggap sebagai sesuatu yang menakutkan. Kekhawatiran ini mungkin berawal dari pemikiran bahwa dirinya akan menjadi tidak sehat, tidak bugar, dan tidak cantik lagi. Munculnya kekhawatiran yang berlebihan itu menyebabkan wanita sulit menjalani masa ini. Datangnya menopause juga merupakan pertanda terjadinya masa transisi yang biasanya diiringi dengan perubahan fisik dan psikologisnya (Jones, 2007).

Perubahan-perubahan fisik yang terjadi selama masa transisi dapat dilihat dari perubahan penampilan kewanitaan yang menurun seperti payudara tidak dilayangkan kepada Debby Anggraini Daulay melalui e-mail:db_daulay@yahoo.com kencang, bibir dan kulit menjadi kering dan kurang halus, rambut beruban, menipis dan mudah rontok, selaput bening mata menjadi lebih kering, lekuk tubuh menjadi rata, dan tubuh relatif menjadi lebih gemuk (Maspaitella, 2006). Selain mengalami perubahan fisik, menurut Gulli (dalam Longe, 2002) beberapa wanita juga merasakan gejala-gejala fisik yang menyertai menopause seperti rasa panas (hot flush) yang biasanya terjadi pada leher, wajah serta bagian atas dada, keluarnya keringat yang terlalu berlebih, sulit tidur, iritasi pada kulit, kekeringan vagina, mudah lelah, sakit kepala, dan jantung berdebar kencang.

Perubahan dan gejala fisik yang terjadi ketika menopause seringkali juga disertai dengan beberapa gejala psikologis.

Rekomendasi mensitasi:

Daulay, D., \& Siregar, N. Z. (2013). Perbedaan psychological well-being antara wanita menopause yang bekerja dengan tidak bekerja. Psikologia, 8(2), 50-58. 
Hurlock (1999) mengungkapkan bahwa wanita menjadi lebih mudah tersinggung, tertekan, gelisah, gugup, kesepian, tidak sabar, gangguan konsentrasi, tegang, cemas, bahkan depresi saat menopause. Kecemasan dan depresi yang dialami wanita menopause umumnya berkaitan dengan kesulitan-kesulitan emosi yang mereka alami pada saat menyesuaikan diri dengan berbagai perubahan hormon dan psikologis yang terjadi selama menopause (Becker, Orr, Weizman, 2007).

Bagi beberapa wanita yang tidak mampu menyesuaikan diri dengan baik selama menopause, kondisi ini akan mempengaruhi kesehatan dan kesejahteraannya. Kesejahteraan sering diistilahkan dengan well-being. Pimenta (2011) melalui hasil penelitiannya tentang menopause dan well-being pada 1003 wanita menopause menemukan bahwa depressive mood yang merupakan simptom menopause secara signifikan berkaitan dengan penurunan well-being seseorang. Well-being sendiri diartikan sebagai fungsi optimal yang dimiliki individu (Ryan \& Deci, 2001).

Menurut Ryff (1989), well-being itu sendiri terkait dengan fungsi psikologi positif yang selanjutnya disebut sebagai psychological well-being. Psychological well-being merupakan realisasi dan pencapaian penuh dari potensi individu dimana individu dapat menerima masa lalunya dengan segala kelebihan dan kekurangannya (self acceptance), menunjukkan sikap mandiri (autonomy), mampu membina hubungan yang positif dengan orang lain (positive relation with others), dapat menguasai lingkungannya (environmental mastery), memiliki tujuan dalam hidup (purpose in life), serta mampu mengembangkan pribadinya (personal growth).

Kenyataannya, tidak semua wanita yang mengalami menopause merasakan dampak negatif dari berbagai gejala fisik dan psikologis seperti yang disebutkan sebelumnya. Beberapa wanita menganggap menopause sebagai hal yang normal dalam hidupnya. Mereka justru menemukan kesenangan selama menopause (Ibrahim, 2002). Hal yang sama juga diungkapkan Lock (dalam Papalia, 2007) melalui penelitiannya terhadap wanita menopause yang menyatakan bahwa wanita-wanita jepang tidak menunjukkan penolakan terhadap menopause. Mereka memandang menopause sebagai masa perpaduan antara integritas, keseimbangan, kebebasan, dan kepercayaan diri.

Hal di atas menunjukkan bahwa beberapa wanita memiliki sikap yang positif terhadap menopause sehingga dapat menerima datangnya menopause dengan baik. Hal ini menunjukkan mereka memiliki psychological well-being yang baik. Hal ini sesuai dengan pendapat Ryff (1995) yang mengungkapkan bahwa salah satu kriteria seseorang dapat dikatakan memiliki psychological well-being yang baik jika seseorang dapat menerima keadaan dirinya, dimana seseorang itu mampu mengakui dan menerima berbagai aspek dalam dirinya baik yang positif maupun negatif, memiliki sikap positif terhadap diri sendiri, dan memandang positif kehidupan yang dijalani sekarang dan juga masa lalunya.

Tingkat well-being pada tiap orang berbeda. Salah satu faktor yang mempengaruhi psychological well-being seseorang adalah kepercayaannya terhadap peran yang mereka jalankan sehari-hari. Sollie dan Leslie (dalam Strong dan Devault, 1989) menjelaskan bahwa Peran yang dijalankan dalam kehidupan seharihari erat kaitannya dengan psychological well-being seseorang. Sebagain besar wanita yang menjalankan perannya sebagai ibu rumah tangga lebih menunjukkan gejala-gejala distress dan ketidakpuasan hidup dibandingkan dengan wanita yang bekerja. Hal ini dikarenakan ibu rumah tangga terkadang merasa jenuh dengan tugas rumah tangga sehari-harinya yang rutin dan monoton. Sebagai anggota masyarakat, mereka juga dituntut untuk ikut berpartisipasi aktif di lingkungan sekitar. Selain itu, ibu rumah tangga lebih 
bergantung pada suami. Hal yang berbeda dirasakan wanita yang bekerja. Bekerja memungkin bagi wanita merasa dapat menjadi lebih mandiri dan tidak bergantung pada suami (Berger, 1999).

Kesehatan wanita selama masa menopause seringkali dipengaruhi oleh kepercayaan mereka akan peran-peran yang mereka yakini. Wanita menopause yang merasakan kepuasan dalam pekerjaanya dikaitkan secara positif dengan tidak adanya gejala-gejala somatis dan psikologis selama menopause. Wanita bekerja juga menunjukkan sedikitnya gejala-gejala menopause yang dialaminya dibandingkan dengan wanita yang tidak bekerja (Dennerstein, Dudley, Guthrie, dan Barret, 2000; Lee, Kim, Park, Yang, Ko, dan Joe 2010).

Griffiths, MacLennan, \& Wong, (2010) juga menyatakan bahwa wanita menopause yang bekerja merasakan kepercayaan diri yang meningkat karena merasa masa ini merupakan pertanda mereka semakin matang dan dewasa serta dihormati oleh rekan kerja. Mereka juga menganggap menopause sebagai keadaan yang justru membuat mereka merasa bebas karena tidak direpotkan lagi dengan menstruasi setiap bulannya. Beberapa dari mereka juga merasa bahwa berhenti menopause bukanlah akhir dari segalanya tetapi merupakan tahapan yang menyenangkan karena mereka umumnya mereka memiliki karir yang bagus pada masa ini (Jones, 2007). wanita yang tidak bekerja, mereka umumnya memiliki kualitas hidup yang lebih rendah dibandingkan dengan wanita yang bekerja. Rendahnya kualitas hidup pada wanita menopause yang tidak bekerja bisa dikarenakan adanya perasaan terjadinya perubahan sosial dalam hidupnya yang dikaitkan dengan penuaan dan perubahan pada tubuh yang dialaminya (Jacob, Hyland dan Ley, 2000).

Kenyataannya tidak semua wanita yang bekerja merasakan hal positif, Beberapa wanita yang bekerja juga merasakan hal yang negatif terhadap menopause. Mereka beranggapan bahwa menopause dan simptom-simptomnya menyebabkan mereka malu, cemas, dan kehilangan kontrol dalam melaksanakan pekerjaan mereka. Beberapa wanita yang bekerja juga mengalami simptom menopause lainnya seperti gangguan mood, mudah lelah, konsentrasi menurun, dan kemampuan mengingat yang berkurang sehingga membuat mereka kurang percaya diri dalam menunjukkan performanya saat bekerja (Griffiths, MacLennan, \& Wong, 2010).

Selain itu peran ganda sebagai ibu rumah tangga dan wanita bekerja juga dapat memberikan tekanan. Beberapa wanita di usia madyanya masih memiliki anak yang belum dewasa sehingga masih memiliki tanggung jawab sebagai ibu, istri dan wanita bekerja (Lindsay dalam Elgar \& Chester, 2007). Berger (1999) mengungkapkan bahwa ketidakpuasan peran dikarenakan peran ganda ataupun ketidakmampuan untuk memenuhi peran utamanya inilah yang dapat menjadi konflik dan menimbulkan berbagai tekanan yang akan menyulitkan wanita menopause saat bekerja. Namun, Tidak bisa dipungkiri bahwa dengan bekerja, wanita juga mendapat dukungan sosial dari rekan kerjanya. wanita yang bekerja dapat membentuk jaringan sosial yang mendukungnya dan bisa berbagi seputar masalah yang dihadapi salah satunya menopause. Orang-orang dalam lingkungan kerja seringkali juga memberikan berbagai informasi yang dapat membantu wanita memandang menopause dengan lebih positif dibandingkan dengan wanita yang jauh dari dunia kerja dan semua waktunya dihabiskan hanya untuk menjadi istri dan ibu rumah tangga saja.

Dari uraian diatas, dapat disimpulkan bahwa menopause menimbulkan berbagai gejala fisik dan psikologis yang dapat mempengaruhi kesejahteraan psikologis (psychological well being) wanita. Kesejahteraan psikologis wanita menopause juga erat 
kaitannya dengan peran mereka. Beberapa wanita yang bekerja memiliki kondisi psikologis yang lebih baik dibandingkan wanita yang hanya menjadi ibu rumah tangga. Oleh karena itu peneliti ingin mengetahui apakah perbedaan psychological well-being antara wanita menopause yang bekerja dan tidak bekerja. Selain itu ingin dilihat juga perbedaan pada keenam dimensi psychological wellbeing yaitu otonomi, penguasaan lingkungan, pertumbuhan pribadi, hubungan positif dengan orang lain, tujuan hidup dan penerimaan diri antara wanita menopause yang bekerja dan tidak bekerja.

\section{METODE}

\section{Partisipan}

Partisipan pada penelitian ini adalah 100 orang wanita menopause yang bekerja dan tidak bekerja. Wanita menopause yang bekerja berjumlah 52 orang dan wanita menopause yang tidak bekerja berjumlah 48 orang. Partisipan diambil secara incidental sampling.

\section{Prosedur dan alat ukur}

Untuk keperluan penelitian ini, angket yang dibuat berisi skala untuk mengukur variabel penelitian. Angket disebarkan kepada partisipan untuk diisi, dan kemudian mengumpulkannya setelah para partisipan menyelesaikan pengisian. Semua aitem dibuat dalam bentuk skala Likert dengan lima titik ( $1=$ sangat tidak sesuai $-5=$ sangat sesuai; sebagian aitem dikonstrukan secara terbalik). Psychological well-being diukur dengan skala adaptasi yang telah dibuat oleh Ryff (1995). Skala ini sudah mencakup keenam dimensi psychological well-being, yaitu otonomi (6 aitem), penguasaan lingkungan (7 aitem), pertumbuhan pribadi (5 aitem), hubungan positif dengan orang lain (8 aitem), tujuan hidup (6 aitem), dan penerimaan diri (5 aitem). Gabungan dari keenam dimensi psychological well-being ini membentuk satu skala psychological well-being yang reliabel (contoh : "saya menilai diri saya berdasarkan apa yang saya pikirkan bukan berdasarkan pendapat orang lain"; 37 aitem; $\alpha=0.930$, corrected item-to-total correlation $=0.33$ sampai 0.72). Total skor yang tinggi menunjukkan tingkat psychological well-being yang tinggi pada wanita menopause dan sebaliknya total skor yang rendah menunjukkan tingkat psychological wellbeing yang rendah pada wanita menopause.

\section{HASIL}

Dalam analisa, respon-respon setiap partisipan pada setiap aitem pada skala psychological well-being ditotalkan untuk menciptakan skala $(29=$ Sangat rendah $-145=$ Sangat tinggi). Analisa Kolmogorov Smirnov menghasilkan $p=0$. 723, menunjukkan sampel penelitian ini terdistribusi secara normal. Analisa levene's test menghasilkan $p=0.211$, menunjukkan varians kedua kelompok sampel sebagai homogen. Hasil perbandingan psychological well-being antara perempuan menopause yang bekerja dengan yang tidak bekerja kami lakukan dengan teknik analisa independent sample t-test dapat dilihat melalui Tabel 1.

Table 1. Perbedaan psychological well-being

\begin{tabular}{lcccc}
\hline \multicolumn{1}{c}{ Status } & Mean & SD & $\boldsymbol{t}$ & $\boldsymbol{p}$ \\
\hline Bekerja & 140.40 & 8.43 & 6.66 & .001 \\
Tidak Bekerja & 126.77 & 12.11 & & \\
\hline
\end{tabular}

Analisa data juga dilakukan berdasarkan tiap dimensi psychological well-being antara wanita menopause yang bekerja dan tidak bekerja dengan menggunakan uji t independent sample $t$ test. Hasil analisa dapat dilihat pada Tabel 2.

Berdasarkan tabel 2, dapat dilihat bahwa ada perbedaan psychological wellbeing antara wanita menopause yang bekerja dengan tidak bekerja pada semua dimensi otonomi, penguasaan lingkungan, pertumbuhan pribadi, hubungan positif dengan orang lain, tujuan hidup, dan penerimaan diri. Hal ini dapat dilihat dari 


\begin{tabular}{llllllll}
\hline Dimensi & Status & N & Mean & Min & Maks & $\boldsymbol{t}$ & $\boldsymbol{p}$ \\
\hline Otonomi & Bekerja & 52 & 20.71 & 14 & 27 & 3.80 & 0.001 \\
& Tidak Bekerja & 48 & 18.58 & 12 & 26 & & \\
Penguasaan & Bekerja & 52 & 26.71 & 19 & 32 & 3.86 & 0.001 \\
Lingkungan & Tidak Bekerja & 48 & 24.50 & 17 & 31 & & \\
Pertumbuhan Pribadi & Bekerja & 52 & 19.04 & 14 & 23 & 2.77 & 0.007 \\
& Tidak Bekerja & 48 & 17.77 & 12 & 24 & & \multirow{2}{*}{0.001} \\
Hubungan Positif & Bekerja & 52 & 30.54 & 24 & 37 & 3.60 & \\
dengan Orang Lain & Tidak Bekerja & 48 & 27.98 & 15 & 26 & & 0.001 \\
Tujuan Hidup & Bekerja & 52 & 24.25 & 16 & 28 & 4.19 & \\
& Tidak Bekerja & 48 & 21.69 & 12 & 28 & & \multirow{2}{*}{0.001} \\
Penerimaan Diri & Bekerja & 52 & 19.15 & 14 & 22 & 5.88 & \\
\hline
\end{tabular}

nilai $\mathrm{p}<0.05$, dimana $\mathrm{p}$ pada tiap dimensinya adalah $\mathrm{p}=0.000,0.000$, 0.007, 0.001, 0.000, dan 0.000. Dari hasil analisa juga dapat dilihat bahwa pada keenam dimensi psychological well-being nilai rata-rata wanita menopause yang bekerja lebih besar dari wanita menopause yang tidak bekerja.

\section{DISKUSI}

Penelitian ini memeriksa perbedaan psychological well-being pada dua kelompok yaitu wanita menopause yang bekerja dan tidak bekerja. Hasil penelitian ini menunjukkan adanya perbedaan psychological well-being antara wanita menopause yang bekerja dan tidak bekerja. Wanita menopause yang bekerja juga memiliki nilai rata-rata yang lebih tinggi dibandingkan dengan wanita menopause yang tidak bekerja. Hal ini sesuai dengan pendapat Ahrens dan Ryff (2006) yang menyatakan bahwa wanita dengan pendidikan yang baik dan melakukan peran ganda menunjukkan tingkat otonomi yang lebih tinggi. Hal ini dikarenakan wanita bekerja dengan tingkat pendidikan yang baik memungkinkan bagi mereka untuk mendapatkan sumber-sumber dan kemampuan yang dapat mereka gunakan untuk mengatur berbagai peran yang mereka lakukan dan dengan demikian mereka merasakan otonomi dalam menjalankan berbagai peran dalam kehidupannya.
Selain itu Azar dan vasudeva (2006) juga mengungkapkan bahwa peran ganda wanita yang bekerja dikaitkan dengan self esteem dan self efficacy yang tinggi. Hal ini dikarenakan peran ganda yang mereka lakukan memberikan kesempatan bagi wanita untuk belajar dari dari berbagai tantangan, mengembangkan self efficacy dan self esteem, memperluas jaringan sosial dan memberikan akses bagi berbagai informasi dan dukungan emosional yang dapat menjadi penahan dari tekanan dan ketegangan hidup. Self efficacy juga dapat menjadi katalisator untuk meningkatkan well-being. Hal ini karena dengan adanya perasaan mampu dalam menyelesaikan berbagai hal mendorong wanita bekerja untuk lebih percaya dengan diri sendiri sehingga memberi pengaruh yang positif bagi kondisi psikologisnya.

Adanya Sense of control pada wanita bekerja juga dapat menyebabkan wanita memiliki psychological well-being yang lebih tinggi dibandingkan dengan wanita tidak bekerja. sense of control inilah yang dibutuhkan seseorang untuk mampu menghadapi berbagai situsai yang berbeda dalam menjalankan peran mereka secara efektif. wanita bekerja yang merasakan dirinya mampu mengontrol berbagai peran yang mereka lakukan menunjukkan tingkat otonomi yang lebih baik (Ahrens \& Ryff, 2006)

Selain berbagai hal yang telah disebutkan di atas, sikap yang positif dalam menjalani hidup juga membantu 
seseorang mencapai well-being yang lebih baik. Griffiths, MacLennan, dan Wong (2010) menyatakan bahwa wanita menopause yang bekerja umumnya lebih positif memandang datangnya menopause dan mampu menjalaninya. Wanita yang bekerja umumnya memiliki rasa percaya diri yang lebih baik. Kepercayaan diri erat kaitannya dengan self esteem seseorang.

Wanita dengan Self esteem yang tinggi menunjukkan penyesuaian diri yang lebih baik terhadap menopause dibandingkan dengan wanita dengan self esteem yang rendah. Wanita dengan self esteem yang lebih rendah sering menunjukkan kecemasan terkait dengan gejala-gejala menopause (Lee, Kim, Park, Yang, Ko, \& Joe 2010).

Perbedaan psychological wellbeing juga dapat dilihat dari masingmasing dimensi psychological wellbeingnya. Pada dimensi otonomi menunjukkan bahwa wanita menopause yang bekerja memiliki mean yang lebih tinggi dibandingkan wanita yang tidak bekerja. Hal ini sejalan dengan hasil penelitian Azar dan Vasudeva (2006) yang menemukan bahwa wanita yang memiliki pekerjaan yang baik umumnya juga memiliki nilai otonomi yang lebih tinggi. Kemapanan dalam pekerjaan dan kemampuan wanita dalam menangani masalah dalam rumah dan pekerjaan melatih wanita lebih mampu untuk mandiri dan melakukan berbagai peran sebagai istri, ibu dan wanita bekerja.

Tingkat penguasaan lingkungan juga ditemukan berbeda. Wanita menopause yang bekerja memiliki nilai mean yang lebih tinggi dibandingkan dengan wanita tidak bekerja. Hal ini sesuai dengan pendapat Azar dan Vasudev (2006) yang menyatakan bahwa wanita yang bekerja umumnya memiliki harga diri dan keyakinan diri yang lebih baik dibandingkan wanita yang tidak bekerja. Hal ini bisa disebabkan bagi wanita yang memiliki pekerjaan yang memungkinkan pengembangan diri dan karirnya dikaitkan dengan meningkatnya harga diri dan kebahagiaan. Adanya keyakinan akan kemampuannya inilah yang dapat membantu wanita untuk mampu menangani berbagai peran dan permasalahan dalam hidupnya (Bandura, 1998).

Wanita menopause yang bekerja juga memiliki nilai mean yang lebih tinggi pada dimensi pertumbuhan pribadi dibandingkan dengan wanita yang tidak bekerja. Hal ini dikarenakan umumnya pada masa paruh baya memberi banyak tantangan, namun demikian juga memberikan banyak kesempatan untuk mengembangkan pribadi. Dengan meningkatnya kepercayaan diri, beberapa wanita memasuki usia madya mampu memutuskan untuk melanjutkan pendidikan ketingkat yang lebih tinggi, memikirkan untuk meningkatkan karir atau berganti pekerjaan yang menurut mereka lebih baik (Legget, 2007).

Wanita menopause bekerja juga memiliki nilai mean yang lebih tinggi dibandingkan dengan wanita tidak bekerja pada dimensi hubungan positif dengan orang lain. Hal ini berkaitan dengan adanya kesempatan yang lebih besar bagi wanita bekerja untuk menjalin hubungan sosial yang lebih luas. Seperti yang diungkapkan Berger (1999) bahwa wanita menopause yang bekerja bisa berbagi solusi terhadap berbagai masalah seputar menopause dengan rekan kerjanya yang dapat membantu mereka mampu menangani berbagai masalah seputar menopause dengan lebih baik. Hal yang sama diungkapkan Kozier (dalam Leggat 2007) yang menyatakan bahwa wanita berbagi solusi terhadap berbagai masalah dengan rekan kerjanya dan memberikan kesempatan bagi wanita untuk memperluas komunikasi yang dapat membantu mereka menangani berbagai masalah sehingga mengurangi resiko stres dan penyakit serta meningkatkan kepuasan diri dan pekerjaan. 
Dimensi tujuan hidup juga berbeda antara wanita menopause yang bekerja dan tidak bekerja. Carr (1996) melalui penelitiannya mengungkapkan bahwa kesuksesan dalam pekerjaan memberi pengaruh yang positif bagi psychological well-being khususnya tujuan hidup dan kondisi psikologisnya. Wanita yang memiliki kepuasan dengan pekerjaannya diusia paruh bayanya umumnya lebih mampu menyesuaikan diri dengan berbagai keadaan. Namun tidak demikian halnya bagi wanita yang tidak bekerja, mereka umumnya memiliki kualitas hidup yang lebih rendah dikarenakan adanya perasaan terjadinya perubahan sosial dalam hidupnya yang dikaitkan dengan munculnya pandangan negatif terhadap penuaan dan perubahan pada tubuh yang dialaminya (Jacob, Hyland dan Ley, 2000).

Wanita menopause yang bekerja juga memiliki nilai mean yang lebih tinggi dibandingkan dengan wanita tidak bekerja pada dimensi penerimaan diri. Hal ini dikarenakan banyak wanita yang bekerja merasakan adanya kepercayaan diri dan harga diri yang lebih baik dibandingkan dengan wanita yang tidak bekerja. Adanya rasa kepercayaan dalan diri seseorang mendorongnya untuk dapat melihat berbagai hal positif yang dimiliki sehingga mereka dapat menerima kelebihan dan kekurangan dalam dirinya. wanita yang bekerja umumnya juga mampu memandang menopause dengan lebih positif dan mampu menerima kondisinya dengan segala perubahan fisik dan psikologis (Griffiths, MacLennan, dan Wong, 2010).

Selanjutnya, kami menyadari berbagai kekurangan dari penelitian ini yaitu, penelitian ini merupakan penelitian komparasi yang mengukur psychological well-being pada wanita menopause ditinjau dari status bekerja. Dengan metodologi seperti ini, penelitian ini tidak memperhatikan variabel-variabel lain yang berpotensi dalam menentukan psychological well-being seseorang.
Yaitu dalam hal ini tidak adanya kontrol pada status sosial ekonomi, padahal status sosial ekonomi merupakan salah satu faktor yang mempengaruhi psychological well-being. Dengan demikian, akan sangat menarik bagi peneliti selanjutnya untuk mempertimbangkan faktor status sosial ekonomi seseorang.

Terakhir, sebagai implikasi praktis, terdapat beberapa saran untuk para wanita agar dapat meningkatkan psychological well-being, yaitu:

1. Pengetahuan mengenai psychological well-being antara wanita menopause yang bekerja dan tidak bekerja dapat digunakan oleh wanita untuk lebih mamahami bagaimana gambaran kesejahteraan psikologis mereka sehingga baik wanita menopause yang bekerja maupun yang tidak bekerja mampu menjalani masa ini dengan lebih baik.

2. Berdasarkan hasil penelitian, diperoleh bahwa wanita menopause bekerja memiliki psychological wellbeing lebih tinggi dibandingkan wanita tidak bekerja, terutama pada dimensi penerimaan diri. Oleh karena itu diharapkan wanita menopause tidak bekerja dapat lebih memahami segala kekurangan dan kelebihan yang ada dalam dirinya sehingga mampu menyesuaikan diri dengan berbagai kondisi.

\section{REFERENSI}

Ahrens, C \& Ryff, C. D., (2006). Multiple roles and well-being: sociodemographic and psychological moderators. Sex Roles 55, 801-815.

Azar, I. A., \& Vasudeva, P. (2006). Selfefficacy and self-esteem: a comparative study of employed and unemployed married Women in Iran. German Journal of Psychiatry, 2005, 111-117. 
Bandura A. (1998). Health promotion from the perspective of social cognitive theory. Psychology and Health; 13, 623-649.

Becker, D., Ozz, A., \& Weizman, A. (2007). Depressed mood through women's reproductive cycle: correlation to mood at menopause. Climacteric, 10, 46-50.

Berger, G.E. (1999). Menopause and Culture. London: Pluto Press.

Carr, D. (1996). The fulfillment of career dreams at midlife: Does it matter for women's mental health? CDE Working Paper No. 96-21.

Dennerstein L, Dudley L, Guthrie E, Barrett-Connor J. (2000). Life satisfaction, symptoms, and the menopausal transition. Medscape Women's Health.

Elgar, K., \& Chester, A. (2007). The Mental Health Implication of Maternal Employment: Working Versus at-home Mothering Identities. Australian e Journal for the Advancement of mental Health.

Griffiths, A., MacLennan, S., Wong, Y. (2010). Women's Experience of Working through the Menopause. The British Occupational Health Reasearch Foundation. The University of Nottingham.

Hurlock, E. (1999).Psikologi Perkembangan Suati Pendekatan Sepanjang Rentang Kehidupan. Edisi Kelima. Jakarta: Erlangga.

Ibrahim, Z. (2002). Psikologi wanita. Jakarta. Pustaka Hidayah.

Jacobs, P., Hyland, M., \& Ley, A. (2000). Self rated menopausal status and guality of life in women Aged 40-63 years. British Journal of Health Psychology. Vol.5 395-411

Jones, M.L. (2007). Menopause for Dummies. $2^{\text {nd }}$ edition. Indianapolis: Wiley Publishing, Inc
Kasdu, Dini. (2002). Kiat Sehat dan Bahagia Di Usia Menopause. Jakarta: Puspa Swara.

Lee, M.S.,Kim, J.H.,Park, M.S., Yang, J., Ko, Y.H., Ko, S.D., \& Joe, S.H. (2010). Factors influencing the severity of menopause symptoms in korena post-menopausal women. Journal Korean Medicine Science; 25, 758-765.

Leggett, D. (2007). The Aging work force-helping employees navigate midlife. Bussines and Leadership. Vol 55. $169-175$

Longe, J.L. (2002). Gale Encyclopedia of medicine ( $2^{\text {nd }}$ ed., Vol 2). Farmington Hills: Gale Group .

Maspaitella, L.M. (2006). Mengatasi Gangguan Emosional pada wanita menopause. Dalam Simposium Nasional PERKUMPULAN MENOPAUSE INDONESIA (PERMI ). [On-Line]. Available FTP: www.klinikmedis.com. Tanggal akses 12 April 2012.

Novi, J., \& Ross, H., (2009). Perimenopause. New York: Informa Healthcare USA, Inc.

Papalia, F. (2007). Human development : A life span approach. Boston. Mc Graw Hill.

Park, J. \& Liao, T. (2000). The effect of multiple roles of south Korean married women professors: Role changes and the factors which influence potential role gratification and strain. Sex Roles, Vol, 43. 571591.

Pimenta, A.F. (2011). Menopause and Midlife: Menopause Symptoms, Body Weight and Well-Being. Disertasi: ISPA Instituto-Universitario.

Ryan, M.R. \& Deci, L.E. (2001).On happiness and human potentials: a review of research on hedonic and eudaimonicwell-being. Annu. Rev. Psychol.. 52:141-660 
Ryff, C. D. (1989). Happiness Is Everything, Or Is It? Exploration on the Meaning of Psychological Wellbeing. Journal of Personality and Social Psychology, 57, 6, 1069 1081.

Keyes, C. L. M. (1995). The Structure of Psychological Well-being Revisited. Journal of Personality and Social Psychology, 69, 4, 719 - 727

Strong, B \& De Vault. (1989). The Marrige and Family Experience (Fourth Edition). St Paul: west Publishing Co. 